\title{
Risk factors for cognitive impairment in school-age children born preterm - application of a hierarchical model
}

\author{
Fatores de risco para alteração cognitiva em escolares nascidos pré-termo - \\ aplicação de modelo hierarquizado \\ Maura Calixto Cecherelli de Rodrigues? ${ }^{1}$ Rosane Reis de Mello², Kátia Silveira da Silva³ ${ }^{3}$ Márcia Lazaro de Carvalho4
}

\begin{abstract}
The purpose was to analyze factors associated with cognitive impairment in very low birth weight (VLBW) children born preterm. A prospective cohort of 65 VLBW children was assessed at the age of eight years using the Wechsler Intelligence Scale for Children. A model for the relationship of variables with the cognitive impairment outcome attributed hierarchical levels: distal (socioeconomic variables), intermediate I and II (perinatal and neonatal variables, post-neonatal variables) and proximal (child health and psychosocial stimulation). A multivariate logistic regression was performed. In the multivariate hierarchical logistic regression, the maternal education $(\mathrm{OR}=0.77,95 \% \mathrm{Cl} 0.63-0.94)$ and number of prenatal visits $(\mathrm{OR}=0.73,95 \% \mathrm{Cl} 0.54-0.99)$ showed a protective association, but the male $(\mathrm{OR}=7.3,95 \% \mathrm{Cl} 1.54-35.3)$ was associated with worse results. The VLBW children cognitive performance in the age of eight years benefits from more educated mothers, better prenatal care, and the baby gender as female.
\end{abstract}

Key words: cognition, child development, risk factors.

RESUMO

O objetivo foi analisar fatores associados à alteração cognitiva na idade escolar de crianças nascidas prematuras de muito baixo peso (PMBP). Uma coorte prospectiva de 65 crianças PMBP foi avaliada aos oito anos através da Escala de Inteligência Wechsler para Crianças. Um modelo para relação das variáveis com o desfecho alteração cognitiva reconheceu níveis hierárquicos: distal (variáveis socioeconômicas), intermediário I e ll (variáveis perinatais e neonatais; variáveis pós-neonatais) e proximal (saúde da criança e estímulo psicossocial). Foi realizada análise de regressão logística multivariada. Na regressão logística hierarquizada multivariada, a escolaridade materna (OR=0,77; IC95\% 0,63-0,94) e o número de consultas no pré-natal (OR=0,73; IC95\% 0,54-0,99) mostraram uma associação protetora; porém o sexo masculino (OR=7,3; IC95\% 1,54-35,3) foi associado a piores resultados. O desempenho cognitivo dos PMBP na idade de oito anos é beneficiado pela maior escolaridade das mães, melhor assistência pré-natal e pelo bebê ser do sexo feminino.

Palavras-Chave: cognição, desenvolvimento infantil, fatores de risco.

The rise in the survival of newborns with lower gestational age and lower birth weight has drawn great interest on the future development of this population. Their cognitive outcomes at school age have been researched in literature, and the cognitive shortfall is the most prevalent sequel in preterm infants of very low birth weight (VLBW ${ }^{1}$.
Neuroanatomical structures would change in preterm infants, but the factors involved in these changes are not yet clarified ${ }^{2}$. Studies held on the possible determinants of cognitive function in the childhood of children born at different gestational ages imply unfavorable socioeconomic

'Doutora em Ciências pela Fundação Oswaldo Cruz (FIOCRUZ). Médica Pediatra coordenadora do Núcleo de Atenção Interdisciplinar ao Recém-nascido de Risco da Maternidade Leila Diniz-Hospital Municipal Lourenço Jorge, Rio de Janeiro RJ, Brazil;

${ }^{2}$ Doutora em Ciências pela FIOCRUZ. Médica Pediatra/Neonatologista. Docente do Programa de Pós-graduação em Saúde da Criança e da Mulher do Instituto Fernandes Figueira da FIOCRUZ). Responsável pelo Ambulatório de Seguimento de Recém-nascidos de Risco, Departamento de Neonatologia, Instituto Fernandes Figueira, FIOCRUZ, Rio de Janeiro RJ, Brazil;

${ }^{3}$ Doutora em Saúde Coletiva pela Universidade do Estado do Rio de Janeiro (UERJ). Médica, Docente do Programa de Pós-graduação em Saúde da Criança e da Mulher do Instituto Fernandes Figueira da FIOCRUZ. Unidade de Pesquisa Clínica, Instituto Fernandes Figueira, FIOCRUZ, Rio de Janeiro RJ, Brazil; ${ }^{4}$ Doutora em Saúde Coletiva pela UERJ. Médica do Departamento de Epidemiologia e Métodos Quantitativos, Escola Nacional de Saúde Pública Sérgio Arouca, FIOCRUZ, Rio de Janeiro RJ, Brazil.

Correspondence: Rosane Reis de Mello; Rua Eurico Cruz 23/301;22461-200 Rio de Janeiro RJ - Brasil; E-mail: rosanemello@gmail.com / rmello@iff.fiocruz.br Conflict of interest: There is no conflict of interest to declare.

Received 10 November 2012; Received in final form 19 March 2012; Accepted 28 March 2012 
conditions and low birth weight as factors negatively associated with cognitive performance in preschool children³.

The singularity of the preterm newborn population does not allow generalizing the research results on the evolution of cognitive functioning in the general pediatric population for schoolchildren born prematurely ${ }^{4}$.

The purpose of this study was to identify the factors associated with cognitive impairment at school age in a VLBW premature newborn population.

\section{METHODS}

This study was held in the city of Rio de Janeiro, Brazil, in a federal tertiary hospital, with school age children (average -8 years old) born in this hospital and prospectively monitored at the outpatient follow-up of newborns at risk. The criteria for the inclusion of newborns included: very low birth weight (less than 1,500 g), gestational age lower than 34 weeks and that were hospitalized in the Neonatal Unit of this hospital between January $1^{\text {st }} 1998$ and August $31^{\text {st }} 2000$. The study excluded patients with genetic syndromes, congenital infections, congenital malformation and small for the gestational age, according to the criteria by Lubchenco et al. ${ }^{5}$. This population was part of a study on risk factors for respiratory disease in the first year of life of VLBW preterm newborns ${ }^{6}$.

The cognitive assessment applied - the Wechsler Intelligence Scale for Children, (WISC-III) ${ }^{7}$ - was performed by two qualified psychologists. The WISC-III is the most used test for intelligence quotient (IQ) applied to children and adolescents aged 6 to 17 years. It consists of 13 sub-tests subjectively stratified into two groups: verbal scale and performance scale ${ }^{7}$.

The outcome (dependent variable) considered was the cognitive performance obtained using the WISC-III total score classified as normal $(\geq 80)$ or impaired $(\leq 79)$. The borderline scores were between 70 and 79 , and the score equal or less 69 corresponded to intellectual disability.

The independent variables were classified in four levels of determination: distal, intermediate I, intermediate II and proximal. Theoretical references obtained from literature review and biological plausibility were accountable for the placement of these variables in the model ${ }^{4}$. The distal variables refer to the socioeconomic level; the intermediate include perinatal characteristics and interventions, neonatal pathologies and post-neonatal characteristics; the proximal assess the influence of the child health condition and psychosocial stimulation factors ${ }^{4}$.

The gestational age was assessed by order of preference by the last menstrual period, by the estimate of early pregnancy ultrasound, and by the New Ballard method ${ }^{8}$. The degree of cerebral hemorrhage was assessed by transfontanellar ultrasound (TFUS) shown in the neonatal period, according to the classification by Papile et al. ${ }^{9}$ The study considered the TFUS with higher degree of hemorrhage. For the diagnosis of bronchopulmonary dysplasia and its severity, the criterion used was the use of oxygen therapy for or more than 28 days and at 36 weeks of corrected age (moderate and severe) ${ }^{10}$. For sepsis, the study considered the presence of clinical signs, laboratory alterations and/or positive hemoculture.

Transient changes in tone were described if present up to 18 months corrected age, and physical and speech therapy interventions before 6 years of age.

The following were considered for health condition (proximal level): respiratory morbidity in the last 12 months (recurrent wheezing, pneumonia or hospitalization); ${ }^{6}$ Z-scores of body mass index (BMI)/age, weight/height and height/age rates to express nutritional status. The BMI/age and weight/height measured acute malnutrition and height/age assessed chronic malnutrition, associated with unfavorable socioeconomic conditions and repeated exposures to adverse events ${ }^{11}$.

The proximal variables were neurological status assed by the evolutionary neurological examination (ENE) $)^{12}$, motor physical therapy and speech therapy intervention.

The study used the bronchopulmonary dysplasia (BPD) risk factor (exposure) to calculate the sample size. Considering a 95\% confidence, $80 \%$ power, $70 \%$ incidence of cognitive impairment in the VLBW population with BPD and $25 \%$ in VLBW children without BPD, the required sample size would be 56 children ( 42 without BPD and 14 with BPD). The calculation and statistical analysis were performed using the application Epi-Info version 3.5 $5^{13}$.

A univariate analysis was performed among the independent variables of each level of determination and cognitive impairment. For most of the qualitative variables, the reference category considered was the one referring to the absence of the feature. For the gender variable, the female was the reference category. For quantitative variables, the lowest value observed was considered as reference.

The variables with statistical significance at the $20 \%$ level in the univariate analysis were selected. The distal level variables were included in a logistic regression model to adjust to each other. Thus, at each level of the hierarchical model, the variables were controlled for the others at the same level and for the higher level ones. In the final model, only the ones with $5 \%$ level statistic significant were used.

The results were expressed as odds ratio (OR) and 95\% confidence intervals.

The study was approved by the Ethics Committee of the Fernandes Figueira Institute, Oswaldo Cruz Foundation, and the children's guardians or parents signed an informed consent term to participate in the research and related assessments.

\section{RESULTS}

The Department of Neonatology received 179 preterm infants with gestational age below 34 weeks and weighing less than 1,500 g. During the hospitalization 
period, 20 children died, four mothers refused to participate in the research and 58 were excluded. The inclusion criteria included 97 children, and out of these, 72 showed up for cognitive assessment in the proposed age: 6 to 8 years. The percentage of loss was $25.7 \%$ due to address change without previous or later notice. The comparison between the study group with the loss group did not show significant differences for socio-demographic, perinatal, and neonatal features.

Out of the 72 children consulted, 65 were able to undergo cognitive assessment. Seven children did not complete the entire protocol of the cognitive assessment (five did

Table 1. Socio-economic features (distal level) and unadjusted odds ratios for cognitive impairment in children born prematurely with very low birth weight in school age-Rio de Janeiro, Brazil.

\begin{tabular}{|c|c|c|c|c|c|}
\hline Variables & $\begin{array}{c}n(\%) \\
65(100)\end{array}$ & Mean [SD] & OR & $95 \% \mathrm{Cl}$ & $p$-value \\
\hline \multicolumn{6}{|l|}{ Distal Level } \\
\hline $\begin{array}{l}\text { Maternal Education (number of total } \\
\text { years studied) }\end{array}$ & & $8.9[3.7]$ & 0.77 & $0.65-0.91$ & 0.0025 \\
\hline $\begin{array}{l}\text { Paternal Education (number of total } \\
\text { years studied) }\end{array}$ & & $9.0[3.4]$ & 0.86 & $0.73-1.01$ & 0.07 \\
\hline Mother's Age & & $27.9[7.9]$ & 0.94 & $0.89-1.01$ & 0.12 \\
\hline Family Income (Reais) & & $1164.5[1040.33]$ & 0.99 & $0.99-1.00$ & 0.04 \\
\hline Number of people per room & & $1.52[1.3]$ & 1.26 & $0.85-1.88$ & 0.25 \\
\hline Number of children $<5$ years old & & $1.1[0.76]$ & 0.54 & $0.18-1.62$ & 0.27 \\
\hline Paternal presence & $41(63.1)$ & & 0.92 & $0.34-2.55$ & 0.88 \\
\hline
\end{tabular}

SD: standard deviation; OR: Odds Ratio; Cl: confidence interval.

Table 2. Variables of intermediate level 1 and 2 concerning frequency, means, and unadjusted odds ratios concerning the cognitive impairment outcome.

\begin{tabular}{|c|c|c|c|c|c|}
\hline Variables & $\mathrm{n}(\%)$ & Mean [SD] & OR & $95 \% \mathrm{Cl}$ & $\mathrm{p}$-value \\
\hline \multicolumn{6}{|l|}{ Intermediate Level 1} \\
\hline Number of Prenatal visits & & $4.7[2.5]$ & 0.79 & $0.62-0.99$ & 0.04 \\
\hline Maternal hypertension & $21(32.3)$ & & 0.67 & $0.23-1.94$ & 0.47 \\
\hline Maternal hemorrhage & $7(10.8)$ & & 0.92 & $0.19-4.50$ & 0.92 \\
\hline Fetus distress & $21(32.3)$ & & 2.12 & $0.74-6.09$ & 0.16 \\
\hline Gestational age (weeks) & & $28[2.2]$ & 0.99 & $0.96-1.02$ & 0.38 \\
\hline Birth weight (g) & & $1089.7[233.6]$ & 0.99 & $0.99-1.00$ & 0.23 \\
\hline 5th minute Apgar (median) & & 8 & 0.72 & $0.46-1.14$ & 0.16 \\
\hline Cephalic perimeter at birth (cm) & & $25.7[1.8]$ & 1.00 & $0.76-1.32$ & 0.98 \\
\hline Male sex & $35(53.8)$ & & 2.43 & $0.79-7.48$ & 0.12 \\
\hline Female sex & $30(46.2)$ & & & & \\
\hline Antenatal corticoid & $44(67.7)$ & & 0.63 & $0.22-1.79$ & 0.38 \\
\hline Neonatal corticoid & $8(12.3)$ & & 4.43 & $0.82-23.91$ & 0.083 \\
\hline Surfactant & $21(32.3)$ & & 2.12 & $0.73-6.09$ & 0.16 \\
\hline Hospitalization time (days) & & $59(26.8)$ & 1.01 & $0.99-1.03$ & 0.23 \\
\hline Tracheal intubation & $16(24.6)$ & & 2.63 & $0.82-8.43$ & 0.10 \\
\hline Mechanical ventilation & $28(43.1)$ & & 3.22 & $1.16-8.97$ & 0.02 \\
\hline Intracranial hemorrhage & $19(29.2)$ & & 1.58 & $0.54-4.62$ & 0.40 \\
\hline HIC grades III and IV & $4(21.0)$ & & 1.88 & $0.98-3.63$ & 0.059 \\
\hline Bronchopulmonary dysplasia & $15(23.1)$ & & 3.26 & $0.97-11.00$ & 0.056 \\
\hline Sepsis & $41(63.1)$ & & 1.59 & $0.57-4.44$ & 0.37 \\
\hline \multicolumn{6}{|l|}{ Intermediate Level 2} \\
\hline Breast feeding & $36(55.4)$ & & 0.59 & $0.22-1.60$ & 0.30 \\
\hline Breast feeding time & & $2.54(3.5)$ & 0.76 & $0.61-0.95$ & 0.01 \\
\hline Cephalic perimeter $(\mathrm{cm})$ at one year old & & $45.9(1.95)$ & 0.88 & $0.68-1.14$ & 0.35 \\
\hline Rehospitalization & $16(24.6)$ & & 0.68 & $0.21-2.16$ & 0.51 \\
\hline Transient change of tone & $45(69.2)$ & & 0.54 & $0.19-1.58$ & 0.26 \\
\hline Previous physical therapy* & $36(55.4)$ & & 0.76 & $0.28-2.0$ & 0.59 \\
\hline Previous speech Therapy* & $31(47.7)$ & & 1.34 & $0.50-3.6$ & 0.56 \\
\hline
\end{tabular}

SD: standard deviation; CI: confidence interval; OR: Odds Ratio; HIC: intracranial hemorrhage; *before 6 years old. 
Table 3. Characteristics of health, physical therapy and speech therapy, and education (proximal level), and unadjusted odds ratios for cognitive impairment.

\begin{tabular}{|c|c|c|c|c|c|}
\hline Variables & $\mathrm{n}(\%)$ & Mean (SD) & OR & $95 \% \mathrm{Cl}$ & $\mathrm{p}$-value \\
\hline \multicolumn{6}{|l|}{ Proximal Level } \\
\hline Current cephalic perimeter $(\mathrm{cm})$ & & $51.4(1.8)$ & 0.9 & $0.7-1.2$ & 0.49 \\
\hline Respiratory morbidity & $23(35.4)$ & & 1.22 & $0.44-3.4$ & 0.70 \\
\hline Hospitalization in the last 12 months & $4(6.2)$ & & 4.03 & $0.4-41.0$ & 0.23 \\
\hline z score $<-2$ height/age & $4(6.2)$ & & 0.8 & $0.1-6.0$ & 0.82 \\
\hline Z score $<-2$ weight/age & $6(9.2)$ & & 0.8 & $0.14-4.2$ & 0.78 \\
\hline Z score $<-2$ BMI/age & $6(9.2)$ & & 0.78 & $0.15-4.2$ & 0.78 \\
\hline Current physical therapy treatment & $5(7.7)$ & & 0.28 & $0.03-2.70$ & 0.27 \\
\hline Current speech therapy treatment & $31(47.7)$ & & 1.34 & $0.50-3.57$ & 0.56 \\
\hline Attended preschool & $52(80)$ & & 0.63 & $0.19-2.13$ & 0.45 \\
\hline Attends public school & $47(72.3)$ & & 3.98 & $1.13-13.9$ & 0.030 \\
\hline
\end{tabular}

SD: standard deviation; OR: Odds Ratio; Cl: confidence interval; BMI: body mass index.

Table 4. Hierarchical logistic regression of the determinants factors of cognitive impairment at school age of very low birth weight preterm infants - Rio de Janeiro, Brazil.

\begin{tabular}{|c|c|c|c|}
\hline & Ajusted OR & $95 \% \mathrm{Cl}$ & $p$-value \\
\hline \multicolumn{4}{|l|}{ Distal level model } \\
\hline Maternal education & 0.76 & $0.59-0.97$ & 0.028 \\
\hline Paternal education & 1.07 & $0.84-1.37$ & 0.58 \\
\hline Mother's age & 0.94 & $0.87-1.02$ & 0.16 \\
\hline Family income (Reais) & 0.99 & $0.99-1.00$ & 0.11 \\
\hline \multicolumn{4}{|l|}{ Intermediate level 1 model } \\
\hline Maternal education & 0.71 & $0.56-0.88$ & 0.002 \\
\hline 5th minute Apgar & 0.96 & $0.45-2.09$ & 0.93 \\
\hline Number of prenatal visits & 0.69 & $0.49-0.98$ & 0.04 \\
\hline Neonatal corticoid & 15.94 & $0.36-708.51$ & 0.15 \\
\hline Bronchopulmonary dysplasia & 1.33 & $0.12-15.21$ & 0.82 \\
\hline Tracheal intubation & 0.24 & $0.02-3.26$ & 0.28 \\
\hline Intracranial hemorrhage-grade & 1.90 & $0.71-5.07$ & 0.20 \\
\hline Mechanical ventilation & 3.95 & $0.28-55.42$ & 0.31 \\
\hline Male gender & 8.42 & $1.23-57.40$ & 0.03 \\
\hline Fetus distress & 1.40 & $0.27-7.15$ & 0.70 \\
\hline Surfactant & 0.43 & $0.03-5.35$ & 0.51 \\
\hline \multicolumn{4}{|l|}{ Intermediate level 2 model } \\
\hline Maternal education & 0.76 & $0.62-0.93$ & 0.007 \\
\hline Number of prenatal visits & 0.74 & $0.55-0.99$ & 0.004 \\
\hline Male gender & 8.00 & $1.74-36.87$ & 0.008 \\
\hline Breastfeeding time (months) & 0.71 & $0.51-0.99$ & 0.04 \\
\hline \multicolumn{4}{|l|}{ Proximal level model } \\
\hline Maternal education & 0.77 & $0.63-0.94$ & 0.01 \\
\hline Number of prenatal visits & 0.73 & $0.54-0.99$ & 0.04 \\
\hline Male gender & 7.37 & $1.54-35.28$ & 0.01 \\
\hline Breastfeeding time & 0.72 & $0.52-1.00$ & 0.05 \\
\hline Attends public school & 1.41 & $0.28-7.14$ & 0.68 \\
\hline
\end{tabular}

OR: Odds Ratio; Cl: confidence interval.

not return to complete the assessment and two had spastic quadriplegia, hindering the application of the WISC scale).

The children were evaluated with an eight years age mean. In the day of the evaluation, the average of body weight was $26 \mathrm{~kg}$ ( $\mathrm{SD}=6.7)$, of height $127 \mathrm{~cm}(\mathrm{SD}=8.2)$ and of cephalic perimeter $51 \mathrm{~cm}$ (SD=1.8). In 6 children (9.2\%), the BMI Z-score <-2, 4 (6.2\%) had low height for the age, and 6 (9.2\%) showed low weight for the age, 4 were obese (Z-scores $>2$ ), and 55 were normal.
Fifteen children (23\%) showed WISC total score below 70 and fifteen (23\%) had a borderline total score, configuring $46 \%$ of abnormal results. There were two children with cerebral palsy (diplegia). The percentage of change in appendicular coordination, static and dynamic balance verified was 23 , 27.7 and $13.8 \%$, respectively.

Data from Table 1 suggest that most of these children belong to a less privileged economic class. The family income 
median was $R \$ 900.00$, ranging from $R \$ 95$ to $R \$ 7,000$. The maternal and paternal schooling, maternal age and family income variables were associated with the outcome.

The Table 2 characterizes the framework of severity for this population. Approximately 30\% $(n=20)$ of newborns weighed less than 1,000g at birth, $15.4 \%(n=10)$ had gestational age lower than 26 weeks, and $13.8 \%(n=9)$ developed with moderate and severe BPD levels.

A higher number of prenatal medical appointments showed to be protective for change in cognitive development. Fetal distress, $5^{\text {th }}$ minute Apgar, and male gender were also significantly associated with the outcome. The use of corticoids by the newborn, despite the high OR, was not associated with impairment in cognition. Among the neonatal pathologies, the degree of intracranial hemorrhage and BPD were associated with the outcome. Regarding the post-neonatal intermediate risk factors, only the time spent on breastfeeding was associated with cognitive development.

The Table 3 points out that one third of children showed respiratory morbidity in the last 12 months and $9.2 \%$ were undernourished. Only the variable "attends public school" showed an association (positive) with cognitive impairment.

The Table 4 shows the results of the hierarchical multivariate analysis. The protective effect of maternal education in relation to cognitive impairment remained at all levels, demonstrating a direct effect of maternal education on infant cognition. The time spent on breastfeeding showed an $\mathrm{OR}=0.72$ (95\%CI $0.52-1.00)$ with borderline $\mathrm{p}$-value $(\mathrm{p}=0.05)$ in the proximal level model. The increased number of prenatal visits and male gender kept their statistical significance up to the proximal level model, respectively demonstrating protective and deleterious effect on cognitive development.

\section{DISCUSSION}

These results confirm how important is maternal education for the cognitive development of preterm infants ${ }^{14}$. More education can increase the chances of employment and, consequently, improve family income. Moreover, a higher level of formal education influences the practice of child care ${ }^{15}$.

Other possible consequences from the maternal education influence on cognitive development undergo controversial issues such as maternal responsiveness (contingent maternal behaviors and immediately related to child behavior $)^{16}$. The cognitive development in children born with VLBW, particularly those with less severe complications, would be positively influenced by consistent responsiveness during first childhood ${ }^{17}$.

Perhaps keeping the association between maternal education and cognitive impairment in the final model pervade through mechanisms related to intermediate and proximal factors not considered in this model, such as stimulation of the child by the parents or guardians, supply of toys and games, organization of a favorable environment and parental practices and styles ${ }^{3}$.

Unlike other studies on cognition in children ${ }^{3}$, family income was not significantly associated with cognitive impairment. Perhaps the homogeneity of the income partially explains this result. Either way, the effect of poverty on cognitive development of children and adolescents is not direct, but mediated by several factors ${ }^{18}$.

The association between the number of prenatal visits and cognitive development is in the original finding of this research. A higher number of prenatal consultations would probably provide, indirectly, beneficial interventions to the baby, such as the use of antenatal steroids and tocolysis in the mother, identified as protective factors for brain anomalies in the newborn ${ }^{19}$. The best care provided by the pregnant woman would imply in a longer gestational period to the birth and favorable clinical conditions at birth for both, mother and baby, and early neonatal period, such as lower incidence of hypothermia and $\mathrm{BPD}^{19}$.

Furthermore, a stronger bond between mother and prenatal care service shows greater propensity to join an outpatient follow-up service for newborns at high risk. This is particularly important for VLBW infants, once it facilitates early detection and intervention of neurodevelopment abnormalities.

The gender of the newborn is a predictor of development, once there is an association between males with worse cognitive and neurodevelopmental results in school children born prematurely ${ }^{20}$.

In the final model of hierarchical multivariate regression, the time spent on breastfeeding and cognitive development showed borderline statistical association $(\mathrm{p}=0.05)$. The meta-analysis held with children of different birth weights and gestational ages found conflicting results. One of them, comparing breast milk feeding after hospital discharge with feeding with formulas ${ }^{21}$, the first group showed higher rates of cognitive development up to school age. The other, held more recently, found no association between breast milk feeding and child's intelligence, pointing out the maternal intelligence as responsible for the effect of breast milk feeding on the child's intelligence ${ }^{22}$.

In premature infants, breast milk feeding in the neonatal period increases the levels of docosahexaenoic acid, which may influence on brain development in the nursing period and in preschool years ${ }^{23}$.

Amongtheproximalfactors, “attendspublicschool” resulted in a nearly four times greater chance of cognitiveimpairmentin the univariate analysis. Its association lost significance in the multivariate model of logistic regression probably as it reflects the effect of maternal education and access to healthcare services (number of prenatal visits) in cognitive development.

The lack of association between nutritional status and cognitive impairment observed in this study had previously been observed in the Brazilian preschoolers' population ${ }^{3}$. 
Studies on the cognitive development of Brazilian cohorts of VLBW preterm infants are scarce. A cohort of preterm infants discharged from the neonatal unit showed lower IQ in preschool age than those found in international literature, though the most affected areas coincide ${ }^{24}$. The Victorian Infant Collaborative Study Group, an Australian study, applied the WISC-III in 8 years old children born between 23 and 25 weeks, and achieved an average IQ of 93, significantly lower than the group of infants born at regular term $^{25}$. In São Paulo, Brazil, the WISC was applied in 20 children aged 9 years that were VLBW premature infants, and showed that $63 \%$ of the group presented normal results and $23 \%$ were classified as mentally handicapped ${ }^{26}$. In this study, the mean IQ obtained from the WISC-III was 80, and $23 \%$ showed IQ $<70$ and $23 \%$ between 70 and 79 .

These differences may be a result from implementation of programs, such as the Infant Health and Development Program (USA), with home visits, full-time educational centers, and regular meetings with healthcare teams and education with parents, as well as assistance and guidance provided by professionals qualified to improve the prognosis of children with motor and/or mental disabilities ${ }^{27}$.

Results from recent studies suggest that socioeconomic factors were more associated with cognitive development in preschool age than biological factors ${ }^{3,18}$. Hence, the importance of implementing public policies for qualified assistance to this population to reduce the impact of social inequalities in the neurodevelopment.

Although the access to professionals such as speech therapists, physiotherapists and psychologists was limited at providing follow-up for this study cohort, the later can be considered "privileged" as this type of specialized outpatient care is scarce in the public network. In the general population of preterm infants in our country, the magnitude of the associations may be higher, once they are not reduced by the follow up of qualified professionals.

Moreover, there is no government guarantee of universal access to preschool. At this stage of life, it is already possible to detect cognitive impairments, which if treated early, may improve school academic performance ${ }^{28}$. In school stage, special academic assistance provided by trained professionals such as psychopedagogy professionals and speech therapists would lead to an actual literacy and school inclusion ${ }^{28}$. In preschool and school ages, the psychometric assessment on development can be a useful tool in the propaedeutic and treatment, but it depends on training and qualification.
The sample size of this study population, which originated from a single public outpatient clinic, may be considered one of the limitations of this paper. Moreover, as it was not able to monitor parenting practices and styles, the environment in which the child lives, together with a study on the neighborhood and on the support network available to this family, as well as the quality of formal schooling provided, also hindered a deeper knowledge about the factors associated with cognitive development at school age.

Although the sample size reduced the statistical power for some associations, which could explain the lack of association with birth weight, gestational age ${ }^{29}$, and degree of intracranial hemorrhage ${ }^{30}$, this study found results consistent with literature and other studies that raise issues for causal mechanisms studies.

The cohort of this study showed many complications in the beginning of life and was composed primarily of lowincome families with unfavorable sociocultural factors, living far from the monitoring hospital. These issues have contributed to the percentage of losses observed in this study. However, as the population of losses resembled the population of study, it is less likely to have a selection bias.

There must be further investigation on the socioeconomic and demographic characteristics to better assess their impact on the cognitive development of preterm schoolchildren. Factors associated with the physical environment in which the child lives and their psychosocial stimulation should be considered as likely to act proximally in the cognitive development and maybe influenced by distal and intermediate factors ${ }^{3}$.

The cognition assessment, construct complex, was limited in the present study to the psychometric assessment by scale for wide use, reliable and with little subjectivity in its interpretation, used as dichotomous (normal or abnormal result) due to the statistical method applied. It was not possible to find out the cognitive impairment degrees. Given these issues and the heterogeneity of the population of preterm and VLBW infants, the generalization of the results for the target population must be carefully made.

In conclusion, in this VLBW preterm infant cohort, the factors that were associated with lower frequency of cognitive impairment at school age were more maternal education and higher number of prenatal visits, and the male gender has been associated with worse cognitive results.

Facing the set of factors that interfere with cognition at school age, healthcare teams that assist this population at risk would be more likely to act prophylactically and therapeutically in the neurodevelopment of these children.

\section{References}

1. Bhutta AT, Cleves MA, Casey PH, Cradock MM, Anand KJS. Cognitive and behavioral outcomes of school-aged children who were born preterm: a meta-analysis. JAMA 2002;288:728-737.

Volpe JJ. Brain injury in premature infants: a complex amalgam of destructive and developmental disturbances. Lancet Neurol 2009; 8:110-124.
3. Santos DN, Assis AMO, Bastos ACS, et al. Determinants of cognitive function in childhood: a cohort study in middle income context. BMC Public Health 2008; 8:202-216.

4. Rodrigues MCC,MelloRR,SilvaKS,Carvalho ML. Desenvolvimentocognitivo de prematuros à idade escolar: proposta de modelo hierarquizado para investigação dos fatores de risco. Cad Saúde Pública 2011;27:1154-1164. 
5. Lubchenco LO, Hansman C, Dressler M, Boyd E. Intrauterine growth estimated from liveborn birth-weight data at 24 to 42 weeks of gestation. Pediatrics 1963;32:793-800.

6. Mello RR, Dutra MV, Ramos JR, Daltro P, Boechat M, Lopes JM. Neonatal risk factors for respiratory morbidity during the first year of life among premature infants. Sao Paulo Med J 2006;124:77-84.

7. Wechsler D. WISC-III: Escala de inteligência Wechsler para crianças. Adaptação brasileira da $3^{a}$ edição. São Paulo: Casa do Psicólogo; 2002.

8. Ballard JL, Khoury JC, Wedig K, Wang L, Eilers-Ealsman BL, Lipp R. New Ballard score, expanded to include extremely premature infants. J Pediatr 1991;119:417-423.

9. Papile LA, Burnstein J, Burnstein R, Koffler H. Incidence and evolution of subependymal and intraventricular hemorrhage: a study of infants with birth weights less than 1,500 g. J Pediatr 1978;92:529-534.

10. Jobe AH, Bancalari E. Bronchopulmonary dysplasia. Am J Respir Crit Care Med 2001;163:1723-1729.

11. Organização Mundial de Saúde. 2007. Available at www.who.int/ growthref/who2007_bmi_for_age/en/index.html. Accessed August 22, 2010.

12. Lefévre $A B$. Exame neurológico evolutivo do pré-escolar normal. $2^{\text {nd }}$ ed. São Paulo: Sarvier; 1976.

13. The Division of Surveillance and Epidemiology, Epidemiology Program Office, Centers of Disease Control and Prevention (CDC). EPI INFO version 3.5 .

14. Chaudhari S, Otiv M, Chitale A, Hoge M, Pandit A, Mote A. Biology versus environment in low birth weight children. Indian Pediatrics 2005;42:763-770.

15. Osório MM. Fatores determinantes da anemia em crianças. J Pediatr (Rio J) 2002;78:269-278.

16. Ribas AFP, Moura MLS. Responsividade materna: uma investigação em contexto urbano brasileiro. Rev Bras Crescimento Desenvolv Hum 2006;16:1-11.

17. Smith KE, Landry SH, Swank PR. The role of early maternal responsiveness in supporting school-aged cognitive development for children who vary in birth status. Pediatrics 2006;117:1608-1617.

18. Guo G, Harris KM. The mechanisms mediating the effects of poverty on children's intellectual development. Demography 2000;37:431-447.
19. Costeloe K. EPICure: facts and figures: why preterm labour should be treated. BJOG 2006;113 Suppl 3:S10-S12.

20. Taylor HG, Klein N, Hack M. School-age consequences of birth weight less than 750 g: a review and update. Dev Neuropsychol 2000;17:289-321.

21. Anderson JW, Johnstone BM, Remley DT. Breast-feeding and cognitive development: a meta-analysis. Am J Clin Nutr 1999;70: 525-535.

22. Der G, Batty GD, Deary IJ. Effect of breast feeding on intelligence in children: prospective study, sibling pairs analysis, and meta-analysis. BMJ 2006;333:945

23. Tanaka K, Kon N, Ohkawa N, Yoshikawa N, Shimizu T. Does breastfeeding in the neonatal period influence the cognitive function of very-low-birth-weight infants at 5 years of age? Brain Dev 2009;31:288-293.

24. Meio MD, Lopes CS, Morsch DS, et al. Desenvolvimento cognitivo de crianças nascidas prematuras de muito baixo peso na idade préescolar. J Pediatr (Rio J) 2004;80:495-502.

25. Anderson P, Doyle L, Victorian Infant Collaborative Study Group. Neurobehavioral outcomes of school-age children who were born extremely low birth weight or very preterm in the 1990s. JAMA 2003;289:3264-3272.

26. Bordin MBM, Linhares MBM, Jorge SM. Aspectos cognitivos e comportamentais na média meninice de crianças nascidas pré-termo e com muito baixo peso. Psiq: Teor e Pesq 2001;17: 49-57.

27. ShonkoffJP, Phillips DA. From neurons to neighborhoods: the science of early childhood development. Washington: National Academy Press; 2000.

28. McCormick MC, Brooks-Gunn J, Buka SL, et al. Early intervention in low birth weight premature infants: results at 18 years of age for the Infant Health Development Program. Pediatrics 2006;117:771-780.

29. Power C, Jefferis BJ, Manor O, Hertzman C. The influence of birth weight and socioeconomic position on cognitive development: does the early home and learning environmentet modify their effects? Pediatr 2006;148:54-61.

30. Patra K, Wilson-Costello D, Taylor HG, Mercuri-Minichi N, Hack M. Grades I-II intraventricular hemorrhage in extremely low birth weight infants: effects on neurodevelopment. J Pediatr 2006;49: 169-173. 